\title{
Prospektif Jerami Padi dan Jerami Jagung Sebagai Sumber Pakan Sapi Potong di Kecamatan Biringbulu Kabupaten Gowa
}

\author{
The Potential of Rice Straw and Corn Straw as a Feed Resources for Beef Cattle \\ in Biringbulu Subdistrict, Gowa Regency \\ Mariam $^{1}$, Jasmal A. Syamsu ${ }^{2 *}$ \\ ${ }^{1}$ Mahasiswa Program Studi Magister Ilmu dan Tekologi Peternakan, \\ Fakultas Peternakan Universitas Hasanuddin \\ 2Laboratorium Teknologi dan Industri Pakan, Fakultas Peternakan \\ Universitas Hasanuddin \\ *Korespondensi E-mail: jasmals@yahoo.com \\ Diterima 12 Juli 2021; Disetujui 30 September 2021
}

\begin{abstract}
ABSTRAK
Kajian ini bertujuan untuk mengetahui potensi dan daya dukung jerami padi dan jerami jagung sebagai sumber pakan sapi potong di Kecamatan Biringbulu Kabupaten Gowa. Pengumpulan data sekunder dari Dinas Tanaman Pangan dan Hortikultura Kabupaten Gowa, Dinas Peternakan dan Perkebunan Kabupaten Gowa dan Badan Pusat Statistik Kabupaten Gowa. Data dianalisis untuk menghitung populasi ternak berdasarkan satuan ternak (ST), produksi bahan kering jerami padi dan jerami jagung (BK), indeks konsentrasi ternak (IKT), indeks konsentrasi pakan (IKP). Berdasarkan hasil analisis diperoleh potensi jerami padi dan jerami jagung di Kecamatan Biringbulu Kabupaten Gowa sebesar 17.316,29 ton BK jerami padi dengan produksi terbesar adalah jerami jagung 76.206,00 ton BK. Daya dukung jerami padi dan jerami jagung sebagai sumber pakan masing-masing 7.590,70 ST dan 33.405,37 ST. Berdasarkan populasi sapi potong saat ini sebesar 4.709,50 ST, maka terdapat peluang penggembangan ternak sapi potong di Kecamatan Biringbulu dengan memanfaatkan jerami padi dan jerami jagung sebagai sumber pakan.
\end{abstract}

Kata kunci: Jerami Padi, Jerami Jagung, Sapi Potong, Biringbulu, Pakan

\begin{abstract}
The objective of the research was analysis the the potential and carrying capacity of rice straw and corn straw as a feed for beef cattle in Biringbulu District, Gowa Regency. Data collection from the Food Crops and Horticulture Office of Gowa Regency, the Department of Animal Husbandry and Plantation of Gowa Regency, and the Central Statistics Agency of Gowa Regency. Data were analyzed to calculate livestock population based on livestock units (LU), dry matter (DM) production of rice straw and corn straw, animal concentration index, feed concentration index. Based on the analysis, the potential for rice straw and corn straw in Biringbulu District, Gowa Regency was 17,316.29 tons of rice straw with the largest production was corn straw 76,206.00 tons of DM. The
\end{abstract}


carrying capacity of rice straw and corn straw as a source of feed were 7,590.70 LU and 33,405.37 LU, respectively. Based on the current beef cattle population of 4,709.50 LU, there is an opportunity to develop beef cattle in Biringbulu District by utilizing rice straw and corn straw as a source of feed.

Keywords: Rice Straw, Corn Straw, Beef Cattle, Biring Bulu, Feed Resources

\section{PENDAHULUAN}

Sapi potong merupakan salah satu ternak yang perlu ditingkatkan di Indonesia, untuk memenuhi kebutuhan daging dalam negeri. Kebutuhan daging di Indonesia setiap tahun mengalami peningkatan tetapi tidak diimbangi dengan produksi daging dalam negeri (Rab et. al., 2016). Permasalahan yang sering dihadapi dalam usaha pengembangan ternak ruminansia adalah pengadaan pakan khususnya pakan serat. Kegagalan pengembangan populasi ternak pada suatu wilayah biasanya akibat dari kurang memperhitungkan daya dukung pakan yang tersedia. Padahal pakan merupakan input terbesar pada system peternakan (Tanuwiria et.al., 2007).

Beberapa sumber pakan asal limbah tanaman pangan yang potensial untuk dapat dimanfaatkan sebagai sumber pakan adalah limbah tanaman pangan seperti jerami padi, jerami jagung, jerami kedelai, jerami kacang tanah, pucuk ubi kayu, serta jerami ubi jalar (Syamsu, 2018). Kecamatan Biringbulu yang didominasi limbah tanaman padi dan jagung yang memiliki potensi untuk dimanfaatkan sebagai pakan ternak sapi potong. Kecamatan Biringbulu merupakan salah satu kecamatan di Kabupaten Gowa Propinsi Sulawesi Selatan yang memiliki potensi untuk pengembangan sapi potong. Hal tersebut didukung oleh luas areal tanaman dan tingkat tanaman pangan khususnya tanaman jagung dan padi. Khusus tanaman jagung, produktivitas tanaman jagung di Kecamatan Biringbulu yang tinggi dibandingkan dengan kecamatan lainnya di Kabupaten gowa. Dengan demikian, memberikan implikasi terdapatnya limbah tanaman pangan berupa jerami jagung yang dapat dimanfaatkan sebagai pakan.

Untuk mengatahui potensi limbah tersebut, maka analisis potensi perlu dilakukan sehingga akan diperoleh data yang aktual dan dapat menjadi dasar dalam peningkatan dan pengembangan sapi potong di Kecamatan Biringbulu Kabupaten Gowa yang lebih terarah.

\section{MATER DAN METODE}


Kajian ini dilaksanakan pada bulan Oktober 2020 sampai dengan Januari 2021. Sumber data kajian ini adalah data sekunder yang diperoleh dari instansi terkait yang meliputi data statistik luas panen padi dan jagung (Dinas Tanaman Pangan dan Horikultura. 2019), jumlah populasi sapi potong (Dinas Peternakan dan Perkebunan. 2016), luas lahan, jumlah penduduk (Badan Pusat Statistik Kabupaten Gowa, 2019), serta data pendukung berupa laporan studi atau kajian dan berbagai sumber literatur lainnya.

Data yang diperoleh dilakukan analisis sebagai berikut.

\section{Jumlah Populasi dan Satuan Ternak}

Untuk menghitung jumlah satuan ternak (ST) sapi potong, dihitung populasi ternak berdasarkan struktur populasi (ekor) dikalikan dengan nilai standar satuan ternak. Struktur populasi diperoleh dari analisis jumlah ternak berdasarkan struktur umur yaitu anak $<1$ tahun, muda 1-2 tahun, dewasa $>2$ tahun. Nilai standar satuan ternak yaitu sapi potong kategori anak 0,25 ST, muda 0,5 ST, dan dewasa 1,0 ST (Syamsu, 2006).

2. Kepadatan Ternak

Kepadatan ternak dibedakan dalam kepadatan ekonomi dan dan kepadatan wilayah (Ditjen Peternakan dan Balitnak 1995). Kepadatan ekonomi ternak diukur dari jumlah populasi (ST) dalam 1000 penduduk, dengan kriteria yang digunakan adalah untuk ruminansia dalam satuan ternak yaitu sangat padat $>300$, padat $>100-300$, sedang 50-100, jarang $<50$. Kepadatan wilayah yaitu jumlah populasi (ST) per $\mathrm{km}^{2}$. Kriteria yang digunakan adalah kategori sangat padat $>50$, padat $>20-50$, sedang 10-20 dan jarang $<10$.

3. Indeks Konsentrasi Ternak

Berdasarkan data potensi ternak (ST), maka dapat dianalisis Indeks Konsentrasi Ternak. Indeks konsentrasi ternak memberikan gambaran tentang konsentrasi sapi berdasarkan jumlah populasi sapi di setiap wilayah desa, atau kecamatan. IKT dihitung menggunakan rumus (Syamsu dan Achmad, 2002):

$$
\mathrm{IKT}=\frac{\text { populasi sapi potong di suatu desa }(\mathrm{ST})}{\text { Rata }- \text { rata populasi sapi potong di kecamatan }(\mathrm{ST})}
$$

- Wilayah desa dengan IKT $\geq 1.0$ merupakan wilayah yang memiliki keunggulan populasi sapi kategori tinggi.

- Wilayah desa dengan IKT 0.5 - <1,0 adalah populasi sedang

- Wilayah desa dengan IKT < 0.5 adalah kategori populasi rendah.

4. Produksi Jerami Padi dan Jerami Jagung 
Berdasarkan data luas areal panen (ha) di suatu wilayah (desa), dilakukan perhitungan produksi jerami padi dan jerami jagung (Syamsu, 2006) sebagai berikut.

Total produksi segar

Total produksi bahan kering

Total produksi protein kasar

Total produksi TDN
$=$ produksi segar $($ ton $/$ ha $) \times$ luas areal panen $($ ha $)$

$=$ produksi bahan kering (ton/ha) $\mathrm{x}$ luas areal panen(ha)

$=$ total produksi BKxkandungan PK $(\%)$

$=$ total produksi BKxkandungan TDN $(\%)$

Nilai produksi segar, produksi bahan kering, kandungan bahan kering, protein kasar dan total digestible nutrient jerami padi dan jerami jagung menurut Syamsu (2006).

5. Daya Dukung Jerami Padi dan Jerami Jagung

Menghitung daya dukung jerami padi dan jerami jagung sebagai pakan sapi potong digunakan beberapa asumsi kebutuhan pakan ternak ruminansia. Asumsi yang digunakan yaitu bahwa satu satuan ternak (1 ST) ternak ruminansia rata-rata membutuhkan bahan kering (BK) adalah $6.25 \mathrm{~kg} /$ hari. Daya dukung jerami padi dan jerami jagung dihitung dengan menggunakan rumus (Syamsu, 2006) berikut ini.

$$
\text { Daya Dukung }(\mathrm{BK})=\frac{\text { Produksi jerami padi atau jerami jagung (ton BK/tahun) }}{\text { Kebutuhan bahan kering untuk 1 ST (ton/tahun }}
$$

\section{Indeks Konsentrasi Pakan}

Indeks konsentrasi pakan memberikan gambaran tentang konsentrasi produksi jerami padi dan jerami jagung berdasarkan produksi bahan kering di setiap wilayah. Indeks Konsentrasi Pakan (IKP) dihitung menggunakan rumus (Syamsu, 2006):

$$
\mathrm{IKP}=\frac{\text { Produksi jerami padi atau jerami jagung (ton BK) di wilayah/desa }}{\text { Rata }- \text { rata Produksi jerami padi atau jerami jagung di kecamatan (ton BK) }}
$$

\section{HASIL DAN PEMBAHASAN}

\section{Karakteristik Sapi Potong}

Jumlah dan struktur populasi sapi potong di Kecamatan Biringbulu disajikan pada Tabel 1. Berdasarkan jumlah populasi ternak sapi potong dalam satuan ekor, dilakukan perhitungan jumlah populasi ternak dalam jumlah satuan ternak (ST) yang dianalisis berdasarkan persentase ternak sapi menurut umur (anak, muda dan dewasa) dan angka 
konversi satuan ternak. Jumlah populasi sapi potong di Kecmatan Biringbulu 5.506 ekor yang tersebar di 11 desa atau kelurahan. Populasi tertinggi terdapat di desa Batuamalonro (1.512 ekor) dan populasi terendah di desa Parangloe (166 ekor).

Jumlah populasi sapi potong berdasarkan satuan ternak seluruhnya 4.709,50 ST, dengan distribusi yaitu sapi anak 39 ST, sapi muda 679,50 ST dan sapi dewasa 3.991 ST. Kecamatan yang menunjukkan jumlah populasi sapi potomg tertinggi terdapat di Desa/Kelurahan Batuamalonro 1.290,75 ST atau sekitar 27,40\% dari total populasi kecamatan, sedangkan populasi terendah terdapat di Desa/Kelurahan Parangloe sebanyak 142,75 ST dengan persentase hanya 3,03\% (Tabel 2).

Tabel 1. Jumlah dan Struktur Populasi Sapi Potong di Kecamatan Biringbulu

\begin{tabular}{llrrrr}
\hline \multirow{2}{*}{ No Desa/Kelurahan } & Jumlah & \multicolumn{3}{c}{ Persentase Ternak (\%) } \\
\cline { 4 - 6 } & & $\begin{array}{c}\text { Populasi } \\
\text { (ekor) }\end{array}$ & Anak & Muda & Dewasa \\
\hline 1 & Berutallasa & 725 & 1,38 & 25,93 & 72,69 \\
2 & Pencong & 662 & 0,76 & 31,57 & 67,67 \\
3 & Parangloe & 166 & 0,60 & 27,11 & 72,29 \\
4 & Lembangloe & 257 & 0,00 & 25,68 & 74,32 \\
5 & Taring & 176 & 0,00 & 33,52 & 66,48 \\
6 & Tonrorita & 372 & 4,03 & 31,18 & 64,78 \\
7 & Borimasunggu & 225 & 0,00 & 0,44 & 99,56 \\
8 & Lauwa & 391 & 6,14 & 26,60 & 67,26 \\
9 & Baturappe & 535 & 1,68 & 26,73 & 71,59 \\
10 & Batuamalonro & 1.512 & 6,02 & 20,24 & 73,74 \\
11 & Julukanaya & 485 & 0,21 & 25,15 & 74,64 \\
& Jumlah & 5.506 & & & \\
\hline
\end{tabular}

Tabel 2. Jumlah Satuan Ternak dan Indeks Konsentrasi Ternak Sapi Potong di Kecamatan Biringbulu

\begin{tabular}{llrrrrr}
\hline \multirow{2}{*}{ No Desa/Kelurahan } & \multicolumn{5}{c}{ Satuan Ternak (ST) } \\
\cline { 3 - 7 } & & \multicolumn{1}{c}{ Anak } & \multicolumn{1}{c}{ Muda } & Dewasa & Jumlah & \multicolumn{1}{c}{ IKT } \\
\hline 1 & Berutallasa & 2,50 & 94,00 & 527,00 & 623,50 & 1,46 \\
2 & Pencong & 1,25 & 104,50 & 448,00 & 553,75 & 1,29 \\
3 & Parangloe & 0,25 & 22,50 & 120,00 & 142,75 & 0,33 \\
4 & Lembangloe & - & 33,00 & 191,00 & 224,00 & 0,52 \\
5 & Taring & - & 29,50 & 117,00 & 146,50 & 0,34 \\
6 & Tonrorita & 3,75 & 58,00 & 241,00 & 302,75 & 0,71 \\
7 & Borimasunggu & - & 0,50 & 224,00 & 224,50 & 0,52 \\
8 & Lauwa & 6,00 & 52,00 & 263,00 & 321,00 & 0,75 \\
9 & Baturappe & 2,25 & 71,50 & 383,00 & 456,75 & 1,07 \\
10 & Batuamalonro & 22,75 & 153,00 & $1.115,00$ & $1.290,75$ & 3,01 \\
11 & Julukanaya & 0,25 & 61,00 & 362,00 & 423,25 & 0,99 \\
\hline
\end{tabular}




\begin{tabular}{lllll}
\hline Jumlah & 39,00 & 679,50 & $3.991,00$ & $4.709,50$ \\
\hline
\end{tabular}

Berdasarkan hasil perhitungan indeks kosentrasi ternak (IKT) di Kecamatan Biringbulu diperoleh dari 11 desa/kelurahan, penyebaran kategori tinggi terdapat pada empat daerah yaitu Berutallasa $(1,46)$, Pencong $(1,29)$, Baturappe $(1,07)$ dan Batuamalonro $(3,09)$. Dari ke empat desa atau kelurahan tersebut, desa/kelurahan yang sangat potensial sebagai basis pengembangan ternak sapi potong yaitu desa/kelurahan Batuamalonro dengan nilai IKT 3,09. Batuamalonro menjadi sangat potensial sebagai basis pengembangan ternak ruminansia khususnya sapi potong karena memiliki populasi ternak sapi potong 1.290,75 ST dan merupakan populasi ternak sapi potong terbanyak di Kecamatan Biringbulu. Hal ini mengindikasikan bahwa ternak sapi potong memegang peranan penting bagi ketersediaan sumber protein hewani di kabupaten Gowa.

Tabel 3. Kepadatan Ternak Sapi Potong di Kecamatan Biringbulu

\begin{tabular}{llccrc}
\hline \multirow{2}{*}{ No } & \multirow{2}{*}{ Desa/Kelurahan } & \multicolumn{2}{c}{ Kepadatan Ekonomi } & \multicolumn{2}{c}{ Kepadatan Wilayah } \\
\cline { 3 - 6 } & & $(\mathrm{ST} / 1000$ jiwa $)$ & Kategori & $\left(\mathrm{ST} / \mathrm{km}^{2}\right)$ & Kategori \\
\hline 1 & Berutallasa & 126,39 & padat & 19,14 & sedang \\
2 & Pencong & 167,75 & padat & 19,85 & sedang \\
3 & Parangloe & 51,24 & sedang & 9,77 & jarang \\
4 & Lembangloe & 94,20 & sedang & 11,55 & sedang \\
5 & Taring & 29,90 & jarang & 7,15 & jarang \\
6 & Tonrorita & 77,13 & sedang & 14,64 & sedang \\
7 & Borimasunguu & 159,22 & padat & 21,80 & padat \\
8 & Lauwa & 142,92 & padat & 32,04 & padat \\
9 & Baturappe & 134,69 & padat & 18,18 & sedang \\
10 & Batuamalonro & 430,11 & sangat padat & 62,96 & sangat padat \\
11 & Julukanaya & 192,12 & padat & 24,54 & padat \\
\hline
\end{tabular}

Berdasarkan kepadatan ekonomi ternak, dengan kategori sangat padat $>300$, padat $>$ 100-300, sedang 50-100 dan jarang < 50, maka wilayah Kecamatan Biringbulu menunjukkan rata-rata kepadatan ekonomi ternak sapi potong masuk dalam kategori padat yaitu 145,97 ST / 1.000 jiwa penduduk (Tabel 3). Hasil ini mengindikasikan bahwa kepadatan ekonomi untuk ternak sapi potong padat jika dibandingkan terhadap jumlah penduduk. Terdapat satu desa yang masuk kategori sangat padat yaitu desa Batuamalonro (430,11 ST/1000 jiwa penduduk), sedangkan daerah yang masuk dengan kategori sedang yaitu Parangloe, Lembangloe dan Tonrorita. Hanya terdapat satu daerah yang masuk kategori 
jarang yaitu daerah Taring (29,90 ST/1000 Jiwa) yang artinya bahwa tidak ada kompetisi antara ternak dengan penduduk di wilayah yang masuk kategori sedang dan jarang dalam hal penyediaan makanan, sehingga biaya pakan untuk kebutuhan ternak relatif cukup murah. Disamping itu, kepadatan ekonomi ternak yang sedang memberikan pula indikasi bahwa di wilayah tersebut jumlah kepemilikan ternak sapi potong oleh peternak masih dalam jumlah relatif rendah, sehingga memungkinkan untuk dilakukan pengembangan populasi. Watuwaya et el., (2020) menyatakan bahwa berdasarkan kepadatan ternak disuatu wilayah sangat kuat dipengaruhi oleh perkembangan populasi ternak, potensi daya dukung lahan pertanian serta jumlah penduduk di suatu wilayah.

Berdasarkan dari kepadatan wilayah, rata-rata masuk kategori padat $\left(21,96 \mathrm{ST} / \mathrm{km}^{2}\right)$ hanya ada satu daerah yang masuk kategori sangat padat yaitu desa Batuamalonro, dan dalam kriteria padat yaitu desa atau kelurahan Borimasunggu, Lauwa dan Julukanaya. Peluang pengembangan ternak sapi potong sangat memungkinkan bila dilihat dari kepadatan wilayah atau daerah yang masuk kategori sedang dan jarang yang ada di Kecamatan Biringbulu. Hal ini menunjukkan bahwa populasi ternak sapi potong masih rendah dibanding luas wilayah, sehingga populasinya masih dapat ditingkatkan.

\section{Produksi dan Daya Dukung Jerami Padi dan Jerami Jagung sebagai Sumber Pakan Sapi Potong}

Jumlah produksi limbah jerami padi pada kecamatan Biringbulu mencapai 17.316,29 ton BK. Hasil analisis indeks konsentrasi pakan limbah pertanian jerami padi, menunjukkan bahwa pada kecamatan Biringbulu masing-masing wilayah desa atau kelurahan memiliki tingkat produksi jerami padi yang berbeda, yang disebabkan oleh jumlah areal panen yang otomatis mempengaruhi jumlah limbah tanaman pertanian yang dihasilkan. Kecamatan Biringbulu dengan Kategori indeks konsentasi pakan yaitu sedang, dimana terdapat tiga desa yang masuk dengan kategori tinggi yaitu Batuamalonro, Baturappe dan Berutallasa yang artinya merupakan wilayah dengan potensi limbah jerami padi yang besar. Potensi limbah tanaman pangan ini dapat dimanfaatkan sebagai pakan untuk ternak sapi potong.

Daya dukung jerami padi di Kecamatan Biringbulu sebesar 7.590,70 ST, dan daya dukung terbesar adalah Batuamalonro 911,86 ST dan Berutallasa 911,34 ST (Tabel 4). Desa atau kelurahan yang paling rendah daya dukung adalah wilayah Julukanaya sebesar 520,77 ST. Berdasarkan indeks daya dukung pakan yang memberikan gambaran rasio daya dukung hijauan pakan ternak dengan jumlah populasi ternak sapi potong di masing-masing desa/kelurahan, terdapat dua desa/kelurahan yang memiliki indeks kategori tinggi yaitu 
Berutallasa dan Batuamalonro artinya ke dua daerah ini mampu mendukung ternak sapi potong dari ternak yang sudah ada saat ini. Sedangkan satu wilayah dengan indeks kategori rendah yaitu Julukanaya berarti ketersediaan hijauan pakan ternak hanya mencukupi kebutuhan populasi ternak yang sudah ada. Menurut Rauf dkk., (2013) menyatakan bahwa setiap wilayah kecamatan memiliki keunggulan atau produksi yang tinggi pada jenis limbah tertentu, yang disebabkan oleh jumlah areal panen tanaman pangan yang juga tinggi sehingga jumlah limbah tanaman pangan yang dihasilkan juga tinggi.

Tabel 4. Produksi dan Daya Dukung Jerami Padi di Kecamatan Biringbulu

\begin{tabular}{clrrrr}
\hline No & Desa/Kelurahan & $\begin{array}{c}\text { Produksi Bahan } \\
\text { Kering Jerami } \\
\text { Padi (ton) }\end{array}$ & $\begin{array}{c}\text { Daya Dukung } \\
\text { Bahan Kering } \\
\text { Jerami Padi (ST) }\end{array}$ & Nilai IKP & Kategori \\
\hline 1 & Berutallasa & $2.079,00$ & 911,34 & 1,32 & Tinggi \\
2 & Pencong & $1.485,00$ & 650,96 & 0,94 & Sedang \\
3 & Parangloe & $1.366,20$ & 598,88 & 0,87 & Sedang \\
4 & Lembangloe & $1.395,90$ & 611,90 & 0,89 & Sedang \\
5 & Taring & $1.485,00$ & 650,96 & 0,94 & Sedang \\
6 & Tonrorita & $1.485,00$ & 650,96 & 0,94 & Sedang \\
7 & Borimasunggu & $1.485,00$ & 650,96 & 0,94 & Sedang \\
8 & Lauwa & $1.485,00$ & 650,96 & 0,94 & Sedang \\
9 & Baturappe & $1.782,00$ & 781,15 & 1,13 & Tinggi \\
10 & Batuamalonro & $2.080,19$ & 911,86 & 1,32 & Tinggi \\
11 & Julukanaya & $1.188,00$ & 520,77 & 0,75 & Sedang \\
& Jumlah & $17.316,29$ & $7.590,70$ & & \\
\hline
\end{tabular}

Tabel 5. Produksi dan Daya Dukung Jerami Jagung di Kecamatan Biringbulu

\begin{tabular}{clrccc}
\hline No & Desa/Kelurahan & $\begin{array}{c}\text { Produksi Bahan } \\
\text { Kering Jerami } \\
\text { Padi (ton) }\end{array}$ & $\begin{array}{c}\text { Daya Dukung } \\
\text { Bahan Kering } \\
\text { Jerami Padi (ST) }\end{array}$ & Nilai IKP & Kategori \\
\hline 1 & Berutallasa & $9.000,00$ & $3.945,21$ & 1,30 & Tinggi \\
2 & Pencong & $7.800,00$ & $3.419,18$ & 1,13 & Tinggi \\
3 & Parangloe & $10.200,00$ & $4.471,23$ & 1,47 & Tinggi \\
4 & Lembangloe & $6.000,00$ & $2.630,14$ & 0,87 & Sedang \\
5 & Taring & $12.000,00$ & $5.260,27$ & 1,73 & Tinggi \\
6 & Tonrorita & $10.200,00$ & $4.471,23$ & 1,47 & Tinggi \\
7 & Borimasunggu & $4.500,00$ & $2.630,14$ & 0,65 & Sedang \\
8 & Lauwa & $5.100,00$ & $2.235,62$ & 0,74 & Sedang \\
9 & Baturappe & $3.603,00$ & $1.579,40$ & 0,52 & Sedang \\
10 & Batuamalonro & $4.803,00$ & $2.105,42$ & 0,69 & Sedang \\
11 & Julukanaya & $3.000,00$ & $1.315,07$ & 0,43 & Rendah \\
& Jumlah & $76.206,00$ & $33.405,37$ & & \\
\hline
\end{tabular}

Jumlah produksi limbah jerami jagung pada kecamatan Biringbulu bisa mencapai 76.206 ton BK (Tabel 5). Terdapat lima daerah dengan potensi produksi limbah tanaman pangan yang besar yaitu Berutallasa, Pencong, Parangloe, Taring dan Tonrorita dengan 
kategori tinggi yaitu nilai IKP $>1$ untuk jenis limbah jerami jagung. Berdasarkan hasil perhitungan bahan kering limbah tanaman pangan berupa jerami jagung pada kecamatan Biringbulu mampu mendukung dan menyediakan pakan BK 33.405,37 ST. Wilayah Taring adalah merupakan wilayah dengan produksi dan daya dukung jerami jagung tertinggi disbanding wilayah lainnya di Kecamatan Biringbulu, yaitu produksi jerami jagung 12.000 ton BK dengan daya dukung sebagai pakan 5.260,27 ST. Zahara dkk., (2016) menyatakan bahwa produksi limbah tamanan pangan yang tinggi berpengaruh terhadap daya dukung suatu wilayah. Dengan demikian dapat dikemukakan bahwa produksi limbah tanaman pangan dapat membantu dalam pennyediaan pakan bagi ternak ruminansia.

\section{KESIMPULAN}

Potensi jerami padi dan jerami jagunng di seluruh wilayah Kecamatan Biringbulu Kabupaten Gowa sebesar 17.316,29 ton BK jerami padi dengan produksi terbesar adalah jerami jagung 76.206,00 ton BK. Produksi limbah tanaman pangan berdasarkan produksi bahan kering untuk jerami padi memiliki daya dukung sebagai sumber pakan 7.590,70 ST dan jerami jagung 33.405,37 ST. Dengan populasi ternak sapi potong saat ini sebesar 4.709,50 ST, memberi peluang untuk pengembangan ternak sapi potong di Kecamatan Biringbulu dengan memanfaatkan potensi jerami padi dan jerami jagung sebagai sumber pakan.

\section{UCAPAN TERIMA KASIH}

Diucapkan terima kasih kepada Kepala Laboratorium Teknologi dan Industri Pakan, Fakultas Peternakan Universitas Hasanuddin dan Pengampu Matakuliah Analisis Sumber Daya Pakan dan Wilayah Program Magister Ilmu dan Teknologi Peternakan atas bimbingan dan arahannya sehingga tulisan ini dapat diselesaikan yang merupakan bagian dari matakuliah tersebut.

\section{DAFTAR PUSTAKA}

Badan Pusat Statistik Kabupaten Gowa. 2019. Kecamatan Biringbulu dalam Angka 2029. Badan Pusat Statistik Kabupaten Gowa, Gowa

Dinas Tanaman Pangan dan Horikultura. 2019. Data Luas Areal Panen Padi dan Jagung Tahun 2019 Kecamatan Biringbulu. Kabupaten Gowa Provinsi Sulawesi Selatan.

Dinas Peternakan dan Perkebunan. 2016. Data Populasi Ternak Sapi Potong pada Kecamatan Biringbulu. Kabupaten Gowa Provinsi Sulawesi Selatan. 
Direktorat Jenderal Peternakan dan Balai Penelitian Ternak. 1995. Pedoman Analisis Potensi Wilayah Penyebaran dan Pengembangan Peternakan. Direktorat Jenderal Peternakan dan Balai Penelitian Ternak, Jakarta

Rab, S. A., R. Priyanto, R., Fuah, A.M., dan Wiryawan, I.KG. 2016. daya dukung dan efisiensi produksi sapi madura dengan pemanfaatan limbah kacang kedalai. Jurnal Ilmu Produksi dan Teknologi Hasil Peternakan, 4 (3), 340-344.

Rauf, J., Syamsu., J.A., dan Ako, A. 2013. Potensi Limbah Tanaman Pangan Sebagai Sumber Pakan Dalam Pengembangan Ternak Sapi Potong Di Kabupaten Polewali Mandar. e-Jounal Program Pascasarjana Universitas Hasanuddin. http:// pasca.unhas.ac.id/ jurnal/files/005dca3cd85c8f938118ae17300a0177.pdf

Syamsu, J.A., dan Achmad, M. 2002. Keunggulan kompetitif wilayah berdasarkan sumberdaya pakan untuk pengembangan ternak ruminansia di Sulawesi Selatan. Jurnal Agribisnis, 6(2), 11-19

Syamsu, J. A., Sofyan, L.A., Mudikdjo, K., Sa'id, E.G., dan Laconi, E.B 2006. Analisis potensi limbah tanaman pangan sebagai sumber pakan ternak ruminansia di Sulawesi Selatan. Jurnal Ilmiah Ilmu-Ilmu Peternakan, 3(4), 291-301.

Syamsu, J.A. 2018. Optimalisasi pemanfaatan limbah pertanian sebagai pakan sapi potong di peternakan rakyat. Prosiding Seminar Nasional Inovasi Teknologi Peternakan dalam Mendukung Terwujudnya Ketahanan Pangan Nasional. Fakultas Peternakan Universitas Halu Oleo, Kendari, 17 November 2018. hal. 1-10.

Tanuwiria, U. H., Mushawwir, A., dan Yulianti, A. 2007. Potensi pakan serat dan daya dukungnya terhadap populasi ternak ruminansia di wilayah Kabupaten Garut. Jurnal Ilmu Ternak, 7(2), 117-127

Watuwaya, B.K., Syamsu, J.A., Budiman., and Useng, D. 2020. Analysis of the potential development of beef cattle in East Sumba Regency, East Nusa Tenggara Province, Indonesia. IOP Conf. Series: Earth and Environmental Science 492 : 012153

Zahara, D.A., Liman., dan Muhtarudin. 2016. Kapasitas peningkatan populasi ternak ruminansia berdasarkan potensi limbah tanaman pangan sebagai pakan ternak di Kabupaten Lampung Selatan. Jurnal Ilmiah Peternakan Terpadu, 4(3), 249-255 